\title{
God's Arrows
}

\author{
Ranka Primorac, University of Southampton
}

\begin{abstract}
The article contributes to scholarly conversations around the global prestige and appropriation of texts and forms, by considering some implications of the role of "Achebe" as an exemplary author figure in the formation and reproduction of Africa's novelistic canon. I begin to propose new categories for critical engagement with "the African novel", via rereading of The Arrow of God alongside Dominic Mulaisho's 1971 The Tongue of the Dumb. Written "after Achebe" and revered for being the first Zambian novel to reach global markets, Mulaisho's novel has also been disparaged for not living up to the literary standards set by the master texts of African realism. I problematize the centre-periphery relations in "the African republic of letters" and Mulaisho's ambivalent positioning within it, by outlining certain key literaryhistorical processes in South-eastern Africa before the fall of Apartheid and by interrogating the critical reception of his novel, which emerged out of those circumstances. While it is true that The Tongue of the Dumb appropriates certain elements of Achebean realism, I contend that it should more properly be read as part of a related but distinct local realist tradition based on Bakhtinian adventure time. The article argues for broadening the spectrum of critical approaches to the reading and circulation of Africa's fictions, and against detracting from Achebe's literary achievement by turning it into a discursive tool for effacing the continent's nonglobalised literary production.
\end{abstract}


'Ta! Nwanu! barked Ulu in his ear, as a spirit would in the ear of an impertinent human child. (Achebe, The Arrow of God, 193)

But the old man jumped up, 'Pagan! What is pagan about African medicine? (Mulaisho, The Tongue of the Dumb, 221)

\section{Introduction: Achebe and the worlds of African literature}

In recent years, critical debates related to the revival of World Literature (aimed at eliminating its traditional eurocentrism and accommodating within it the conceptual and political achievements of postcolonial literary studies) have opened up possibilities of new kinds of scholarly conversation about African literature. Following and alongside critical approaches that (among other things) problematized the placement, presentation and marketability of textual production marked as "African" in the global literary marketplace (Huggan, Casanova, Brouillette), scholars relying on versions of world systems theory have produced paradigm-shifting analyses of the formal and semantic implications of African texts' comparative global positioning (Brown, WReC). Some have called for a reconfiguring of specific analytical categories within "African literature" (Julien); others have analysed the spatio-temporal implications of Africa's literary texts and the very meaning of the idea of "world" to which they may be related (Hitchcock, Cheah). This article places Chinua Achebe's 1964 masterpiece, The Arrow of God, at an intersection of several strands of such critical debate, in order to consider a neglected aspect of the discursive authority of "Achebe" as a key regulator of the formal and geographic boundaries that usually circumscribe the category "African literature".

Achebe is a nodal figure in what Pascale Casanova has called the world republic of letters. Often taken as a literal embodiment of African literariness, Achebe's opus enables several kinds of cultural identification: Igbo, Nigerian and African (among others). These 
categories are, in some contexts, subsumed to one another: at other times, they exist in a state of uneasy tension. On this occasion, I am interested in the complex institutional and textual effects that Achebe's status as a foundational African literary figure may have produced in the parts of the continent's geography not normally visible on the global literary map: postcolonial Zambia provides an illuminating case study in this respect. The article draws on recent scholarship on Achebe's realism and the world's literary systems in order to bring The Arrow of God into dialogue with an iconic Zambian novel: The Tongue of the Dumb by Dominic Mulaisho.

In juxtaposing novels by Achebe and Mulaisho within a single analytical frame, I do not aim to perform an immanent "close reading", or a scrutiny of one-directional literary "influence", or an exercise in comparative aesthetic evaluation. Instead, I place these two strategically selected fictions into dialogue in order to scrutinise their temporal (and therefore generic) aspects. Such scrutiny, in turn, provides me with an entry point into charting a particular intersection of genres and textual histories related to what might be termed (in a modification of Casanova's influential title) the African republic of letters. The combination of Pan-Africanist cultural legacy and the economic difficulties besetting most African publishing sectors mean that there exists a great deal of cross-border solidarity among the producers and consumers of African print cultures (see, for example, Bgoya and Jay). And yet, as I aim to demonstrate, solidarity as well as competition can be instrumental in cultural occlusion. I maintain that, as an authorial signifier, "Achebe" was instrumental in the production of a concept of African literature whose global prominence contributed towards making certain other kinds of Africa's literary production invisible (and, more dangerously, unthinkable), and I begin the work of recuperating a specific strand of such submerged literary production. 


\section{Achebe, Mulaisho and the African republic of letters}

When Tongue of the Dumb (henceforth, Tongue) was first published in Heinemann's African Writers Series (AWS) in 1971, civil servant Dominic Mulaisho became the first Zambian author to reach global book markets - an achievement that still reverberates in Zambia's cultural memory, as the obituaries that followed Mulaisho's death in 2013 testify. The novel, Mulaisho's first, was clearly inspired by Achebe's village fictions - arguably Arrow of God (henceforth, Arrow) in particular. In that sense, Achebe's effect on Zambian writing in English has been enabling. This article is, however, concerned with a more ambivalent local aspect of the legacy of "Achebe" as an iconic author figure. The authorfunction, says Foucault, "explains the presence of certain events" in texts and textual traditions (1484). No postcolonial Zambian novelist has attained comparable global visibility since Mulaisho's AWS breakthrough. ${ }^{1}$ Zambian literature did not live up to the hopes of those of its early practitioners who eagerly awaited a "breakthrough in our literary development" in the first decades after independence (New Writers Group). This article reads Arrow alongside a text that represents an African national canon which has, to this day, remained almost entirely outside the literary field globally sanctioned as "African". As Madhu Krishnan avers, the notion of "African literature" has always been surrounded by tensions, divisions and anxieties (171). This article points to a specific, critically neglected, cultural location of such disjunctures.

In a recent Facebook post, a member of the public group Zambian Authors wonders why "Zambian authors fail [to] obtain international recognition as compared [to] other African Authors n [sic] countries like Nigeria, Ghana, Kenya etc" (Wamulume). The post succinctly reproduces a well-worn Zambian critical trope. Its mention of Nigeria as the first among Africa's literary superpowers is not accidental. The authorial signifier "Achebe" is complexly positioned in Zambia's public discourse. It is invested with Pan-Africanist cultural 
pride, yet it often also acquires as its ghostly referent a discursive and material non-event: the canonical path of literary "development" that Zambia did not follow, akin to the disappointments of economic and social expectations of postcolonial modernity that James Ferguson writes about. In 1979, author and critic Masautso Phiri provided a particularly telling example of such an ambivalent cultural stance when he began a critical survey of Zambian writing by bemoaning the "non-emergence [in our midst] of a Chinua Achebe or a Ngugi wa Thiong'o" (34), thus placing the literary validity of the entire outline of Zambia's literary production that follows (which includes a discussion of his own practice) in doubt.

The melancholia that haunts Phiri's words can begin to be analytically addressed if we foreground the notion of an African literary nation-state. In 1960s and 70s, the AWS was the main vehicle for canonising literary Africa. "Achebe" became emblematic of the series as both author and editor. Clive Barnett's discussion of the series highlights the fact that it facilitated the production discourses of Pan-African cultural nationalism by participating in institutional mechanisms of book production, distribution and consumption that were both transnational and transcontinental. Yet individual volumes always named their authors' nation-state of origin, inscribed in each book's para-textual apparatus as a location of difference, which the book's contents were meant to elucidate. Barnett's analysis sets aside Laura Chrisman's injunction to scholars to pay more attention to the "national constituents" of large geographical, economic and social entities (such as "the West" - 74). This article returns to Chrisman's call in the African context, while taking heed of Barnett's findings. The tension between cultural investments and identifications vested in the idea of Pan-Africanism on the one hand, and state-framed African nationalisms on the other, goes a long way towards explaining the ambivalence that shadows Zambia's literary-critical discourse. This ambivalence, in turn, reveals much about the discursive mechanisms which both produced and policed the idea of "African" literary value. 
Pascale Casanova conceptualises the world's literary marketplace as an arena of competition and domination among literary nation-states (regulated, nevertheless, transnationally from the global literary capitals: Paris, London and New York), rather than merely texts and authors. Her choice of examples with which to illustrate Africa's emergence into global literary modernity underscores (without explicitly articulating) the fact that some African literary nations are more globally prominent - more world-canonical - than others. The long tradition of solidarity among Africa's literati only partly counter-acts this disparity. In an essay titled "Can we correct literary barrenness in East Africa?" (first published in the Uganda-based journal Transitions in 1965) Taban Lo Liyong writes about a group of African students in America who engage in a cultural contest of sorts, as they try to out-do one another in evoking their home countries' literary prestige. "Though it hurt my national pride," he writes, "inwardly, I could not help admitting that Nigeria (...) has definitely the greatest number of writers.” (29)

Taban's provocative, humorous intervention represents the African literary space as uneven and discontinuous from its very inception. Globally recognised forms of literariness (the condition of "having writers" visible in the literary marketplace and able to be discussed from a vantage point in the literarily "developed" West) have, since the era of decolonisation, continued to be unevenly distributed across Africa's geography. These discontinuities areconfigured by national boundaries - which, in turn, participate to this day in the reproduction of the idea of Africa as a united and discrete literary space, by making authors and texts eligible for literary prizes and for inclusion in compendia and anthologies. The website of The Caine Prize for African Writing (arguably, AWS's twenty-first-century successor), for example, states that submissions should specify "which African country the author comes from". Pan-African solidarity and the role of AWS in the first wave of the 
global marketing of literary Africa only partially obscure the existence of centres and peripheries of "African" literary visibility and prestige.

Michael R. Ward's 1986 description of Zambian literature as "one of the smallest national literatures in Anglophone Africa" is still accurate today (Hale 211). ${ }^{2}$ Nigeria is, by contrast, one of the strongest and most influential. Its literary prestige is synecdochically connected to Achebe's proper name, which is also a key signifier for the literariness of a continent. Yet in the rhetorical movement from author-figure to continent and back, the institutional determinants defining Achebe's status as a globally recognised author, the value judgements about what constitutes great African literature, and the impact of these determinants and judgements on the production, circulation, and reception of texts elsewhere in the literary African space are eclipsed. From a standpoint within a peripheral African location (such as, for example, Zambia's capital, Lusaka), it becomes possible to see with particular clarity that the inclusion of national canons within the African republic of letters is far from a straightforward matter of geographical location. Such consecration is predicated in part on the international prestige and commercial viability of textual forms. The global literary market is "much more likely to register the presence of writers who adopt generic and modal conventions readily assimilable by Euro-American readers than of writers who root their work in other conventions" (Lazarus 26). The single most important formal vehicle of the emergence of "African literature" (or, more importantly in the present context, "the African novel") into global literary visibility is the variant of novelistic realism pioneered by Achebe.

In recent years, scholars of World Literature have argued persuasively for a need to make world literary studies more inclusive. Neil Lazarus and the Warwick Research Collective (WReC) have critiqued literary postcolonialism's apparent preference for modernist stylistic formations, arguing that the emancipatory potential of critically-neglected 
global realisms, which they also call 'peripheral realism', merit increased scholarly attention. In the present context, their argument must be tempered by the fact that Achebean realism has, if anything, become over-canonised as an "African" postcolonial form of expression. Since the consecration of Achebe as a canonical postcolonial African author has been widely discussed in critical studies of Achebe, it will suffice to quote Stephanie Newell's brief but illuminating comment on Things Fall Apart as an exemplary case in point: "Here is a novel that postcolonial critics refuse to put down", writes Newell of Things Fall Apart (95). If the canonisation of Achebean realism complicates the terms of the Warwick collective's approach to the formal innovations of peripheral realism, this is not to suggest that their call for a broadening out of systematic critical scrutiny is unwarranted. On the contrary, a more nuanced consideration of peripheral literary forms and styles, which also takes account of ostensibly "popular" genres that do not fit the mould of Achebean realism, can work to illuminate and question the core-periphery dynamics which both produce and police African literary value. Indeed, as I go on to suggest, a careful re-assessment of the use of the temporal codes and conventions of the adventure plot in Mulaisho's The Tongue of the Dumb can help to alter the assumptions and value judgements that define and delimit the boundaries of African literary space - not, however, only in the direction of Africa's post/modernisms, but also in order to draw critical attention to the globally differently assimilable formal spectrum of adventure fiction, in which Tongue participates.

Franco Moretti's engagement with the challenge of what he calls the "great unread" (45) is helpful in this respect. First articulated in an influential essay "Conjectures on World Literature", Moretti's interest in how non-canonical texts and formations contribute to the world's literary flows acquires an unexpected relevance in Africa. Non-canonical, nonglobalised fictional production comprises the literary outputs of large swathes of Africa's textual geography. Yet this output cannot always be subsumed under the category "popular 
fiction", as I have argued elsewhere for the case of writing published in the pioneering Zambian journal New Writing from Zambia (“Legends”). Casanova has called such globally invisible geo-cultural locations "literarily destitute" (84); Zambia itself has sometimes been described as a "literary desert" (Roscoe and Msiska 181). A comparative reading of Arrow and Tongue can help to pin-point the transnational policing of genre that underpins the critical devaluation of peripheral African literatures such as that of Zambia in the African republic of letters. Paying close attention to the existing critical readings of the two novels' formal properties, I argue that both Achebe's and Mulaisho's work has, on occasion, been mis-literarised - that is to say, admitted to the status of being literary (Casanova 136) on mistaken premises. Achebe's "ethnographic" realism has often been regarded as an “objective" (Lindfors 25) expression of African cultural authenticity, and Mulaisho's departures from it - as a derivative, empty, culturally inauthentic form. WReC's theorisation of peripheral "fighting" realisms provides a useful springboard into forging critical vocabularies with which to turn "literary deserts" into more complexly examined cultural and literary locations.

I start from the two novels' formal and thematic similarities. Both novels embody versions of what Abdul JanMohamed calls Manichean aesthetics - a post/colonial fictional preoccupation with representing colonial difference. Like Arrow, Tongue narrates the slow, intermeshed unfolding of social and institutional politics in two counter-posed, adjoining communities (one African, one European) in the colonial era. More specifically, both novels are centrally preoccupied with religious reciprocity and conversion; in each narrative, the protagonists grapple with the question of how individuals and social groups relate to the sacred. The textual affinity between Arrow and Tongue is related to the presence in both novels of detailed representations of village life and custom, as well as to their plot and character configurations. Yet there are also substantial formal divergences between them, 
which point to their different geographical, social and political positioning and textual genealogies, as I outline below.

The plot of Arrow is situated in 1920s West Africa and centred on the Igbo priest Ezeulu who becomes "the victim of an alienating world while being a central and indispensable part of it" (Quayson 43). The plot of Tongue is situated in the 1940s. It involves concurrent power struggles in the village of Chief Mpona of the Nsenga people in the south-east of present-day Zambia, and the nearby Jesuit mission. In the village, the evolving conflict is between Mpona and his Councillor Lubinda, who wants access to political power and to the bodies of village women. At the mission, the intransigent and violent Father Oliver (allegorically nick-named Chiphwanya - the crusher - by the villagers) contests the institutional authority of Gonzago, the Father Superior, who has "gone native". Chiphwanya's incursions into village life have divested Mpona of traditionally understood authority and rendered him open to accusations of witchcraft. The narrative is punctured by the interventions of a third group of agents, who are representatives of the colonial state. Such representatives include the District Commissioner, who writes disparagingly on the savagery of Africans in his tour book following a visit to the village. The temporal structure of the narrative is, furthermore, configured by recurring natural disasters: locusts, flooding, crop-killing frost. Just as Arrow of God culminates in a political crisis precipitated by food shortages, so in The Tongue of the Dumb, internal divisions and external threats produce a deepening crisis that culminates in a famine. At the novel's end, an alliance between village and mission is effected by twofold means: a sacrifice and a conversion.

This article's epigraphs are taken from pivotal episodes in each novel. The first epigraph cites the words with which the Igbo god Ulu reproaches the protagonist of Arrow, his priest Ezeulu, for disobedience. The consequences of this confrontation determine the rest of the novel's plot, which culminates in the destruction of both the old priest and the Igbo 
spiritual practice - a tradition which the novel itself, however, symbolically recuperates and makes visible as a "basis for a new, postcolonial beginning" (Gikandi "Arrow of God: the Novel" 14 - to be replaced by a page no. in this issue). The second epigraph is from an analogous scene in Mulaisho, also set in a time of crisis. The speaker is a Jesuit priest based in the south-east of colonial Zambia. He is ill: the epigraph gives his response to being reprimanded for relying on "pagan" African medicine instead of going to hospital. This, too, is the turning point in a fictional representation of oncoming modernity: the old priest's death provides the basis for the emergence of an African Christianity that provides the cultural basis of Zambian nationhood. In their respective novels, then, each of these dialogic moments leads to (what may be read as) personal sacrifice and radical social change that prefigures decolonisation. Yet the two novels' respective conceptualisations of suffering, sacrifice and conversion are differently narratively constructed and (my main point of focus here) generically framed.

\section{Africa's realisms: the "astounding concreteness" of the ethnographic novel}

Achebe's "counterfiction[s] of Africa" (Irele 2) provided the foundations of African Literature as an international pedagogical field, a globally recognised public space "in which Africans could write for and about themselves" (Barnett 74), and "a cornerstone in the project of recuperating a positive notion of African culture and heritage" (Krishnan 132). These achievements are predicated on Achebe's deployment of a specific textual form. In a critical discussion of postcolonial acts of "writing back", John Thieme emphasizes the complexity of the relationship between counter-texts and "originals" by reminding readers that "the influence of the 'original' c[an] seldom be seen as simply adversarial" (2). It is a textual hallmark of Achebe's village novels that they imagine early twentieth-century Igbo life "with 
astounding concreteness" (Brown 104). In doing so, they appropriate certain generic conventions of European realism: stylistic transparency, multi-strand plotting, a detailed, description-rich representation of characters' social and psychological positioning, a propensity towards social analysis and the narrative embodiment of what M.M. Bakhtin calls historical time.

Writing about the representation of change in realist Bildungsromane, Bakhtin describes historical time as the temporality of "transition between two epochs", accomplished "in and through" fictional characters (Speech Genres 23). "The organising force held by the future is therefore extremely great here", he stresses (23), adding that aspects of this type of representation of individual/social emergence can be found "in almost all important realistic novels" (24). Writing about Arrow, Nicholas Brown echoes Bakhtin's wording as he underscores the correlation between Achebe's deployment of historical time, the rise of African realism and what may be construed as epochal change in the history of Nigeria's modernity, the emergence of its anticolonial bourgeoisie. He writes: "as with the great European historical novels, this orientation toward the future has everything to do with the emergence of a new and progressive social class" (104).

The village novels' "astounding concreteness" is largely to do with their detailed descriptions and narrative elaborations of Igbo everyday life. Roland Barthes links the thick descriptions of European nineteenth-century realist novels to a historically new, fantasmatic mode of verisimilitude, whereby a simulacrum of referentiality flies in the face of plot advancement and thus "appears as a resistance to meaning; this resistance confirms the great mythic opposition of the true-to-life (the lifelike) and the intelligible." (146; emphasis in the original.) The political and aesthetic effectiveness of Achebe's detailing of Igbo cultural practice ("what has been") lies precisely in their ability to decentre and disqualify colonial modes of cultural intelligibility, as the many critical engagements with Achebe's relationship 
to Carey and Conrad elaborate. Yet one of the effects of the village novels' success in producing a seemingly "naked" illusion of "the [Igbo] real" has been a trajectory of critical/institutional disregard for the fantasmatic quality of the realist referent. Graham Huggan outlines the irony-laden process through which Achebe's subversions of colonial stereotypes have been absorbed into institutional and market-driven modes of consumption and circulation under the sign of anthropological authenticity convertible into "the postcolonial exotic" (35-43). A parallel outcome of the village novels' quasi-referential verisimilitude is the attempt of some critics to interpret and prescribe Achebean textual strategies as the sole literary method of anchoring Africa's cultural uniqueness and moving "beyond European realism" (Chinweizu). In the contexts of such mimetic readings, Achebe's appropriation of realist form becomes freighted with the double burden of regulating both what passes for "African literature" and for "African reality". This framing of Achebean realism also works to produce a model of African literariness against which other literary texts are adjudged. In postcolonial Zambia, for instance, Mulaisho's Tongue came to be critically evaluated partly in the light of ideas about truth and form that "Achebe" had helped to engender. ${ }^{2}$

In a short essay dedicated to Arrow's formal properties, Simon Gikandi adopts a more nuanced view. He points out that the novel seems "to reflect all the conventions of the realist tradition of the novel dominant in Europe in the nineteenth century" ("Arrow" 489, emphasis added). Yet the late chapters - in which Ezeulu is displaced against his will and a social crisis becomes acute - make it plain that Arrow is in fact complexly positioned on the realism/modernism formal continuum. Like Things Fall Apart, Achebe's third novel is invested in representing and recuperating a knowable Igbo social system, situated in historical time and propelled by a detailed representation of "the quotidian and the everyday as the very measure of a polity" (“Arrow" 491). But its narrative logic also revolves around 
the protagonist who turns out to be a split ("schizophrenic") subject, and whose "interiorised experience" of the world is consistently foregrounded. ("Arrow" 495)

These textual traits are aligned with European literary modernism. Famously opposed to the Conradian critique of modernity and its reading of Africa as the place outside history, Achebe, nevertheless, could not do without modernism's "impressionism, its deployment of fetishistic figures, and its dependence on the irrational" ("Arrow" 493) in his representation of the Igbo encounter with modernity. The textual make-up of the novel, then, combines elements from a number of formal traditions (including, of course, a transposition of Igbo oral genres, famously incorporated into Achebe's representation of the quotidian). In that sense, Arrow fits in well with WReC's description of formally diverse "fighting realisms" from global economic peripheries. Such peripheral realist formations (invested not only in mapping the contours of present-day social orders, but also in tracing possible and emergent futures) occur in periods of radical social change that Frederic Jameson describes as moments of "a history in movement and a future on the point of emergence" (cited in WReC 78). Jameson's phrase is in keeping with the fact that, in Nigeria, globally recognisable realist fictional forms emerged at the time of nationalist struggle for independence.

A key element used by Arrow to "complicate the process" of its own realism (Gikandi "Arrow"192) relates to the novel's entextualisation of a crisis of temporality. The nodal point of this crisis is the dialogic exchange between Ezeulu and his deity to which I referred earlier. This is the moment when Ezeulu has to decide how to deal with the temporal rupture that has occurred as a result of his being detained outside his village by colonial officials. The reproduction of the Igbo lunar calendar has been deferred, causing a communal crisis. On his return, Ezeulu is probing, "with the sensitivity of a snail's horns" (192), the possibility of deviating from established ritual and thus effecting a reconciliation with his people, who have in the past sided with the priest of a rival deity. The words "Ta! Nwanu!" that Ulu "barks" 
into the old priest's ear mean: "Shut up! This child!" in Igbo. ${ }^{3}$ The novel allows for different readings of this event. Simon Gikandi has argued that Arrow's reliance on the narrative technique of free indirect discourse when representing Ezeulu's internal life indicates that the novel does "not provide a time outside of modernity" ("Arrow of God: The Novel" 11; see also Reading 59). In this reading, Ezeulu's questioning of the ontological functioning of "tradition" is always-already performed from a temporal standpoint outside it, and the decision not to reconcile with his people is motivated by his will to power. Yet the words “Ta! Nwanu!” in the episode I have just recounted are, crucially, given in untranslated Igbo via direct speech. This carefully placed narratological detail opens up the possibility of an alternative spectrum of readings. A position on this spectrum has recently been articulated by Mark Mathuray, who takes the exchange between Ezeulu and Ulu to represent the intervention of a "most literal deus ex machina" (40), which turns the Chief Priest into a sacrificial figure. For Mathuray, this episode introduces into the text the surplus of meaning which jolts it out of classical realist verisimilitude. His chosen descriptor for the novel's fracturing of European realist form is "alienated realism" (40) - an appellation entirely in keeping with both Gikandi's description of the novel's modernist elements, and WReC's insistence on the formal complexity of peripheral fighting realisms. In Africa, I maintain, such complexity comes in more shapes than one.

\section{Africa's realisms: "fidelity, valour, bravery, virtue"}

Character alienation also looms large in Mulaisho's novel, as does the idea of a resonance between Christianity and indigenous religious practice. The transactions between Christian and Igbo rituals are enabled in Arrow by the textual play around Ezeulu's exchange with Ulu and sustained until the novel's final phrase about future Umuaro harvests occuring "in the 
name of the son" (232), through which the words "Ta! Nwanu!" reverberate. Tongue echoes Achebe's village novels which inspired it in paying attention to Nsenga everyday life. The novel represents visits between male friends, communal gatherings, the activities of women and children and everyday conversations comprising English transpositions of Chewa phrases and proverbs. Its surface texture involves the use of heterodiegetic narrator, stylistic transparency and shifting focalisation - formal elements which are also compatible with Achebean realism. Mulaisho, furthermore, critiques Imperial discourse and its inability to apprehend local cultures via an unmistakeably Achebe-inspired gesture of ironic decentring: on visiting a village, a District Commissioner writes in his tour book: "Visited Mpona village $24^{\text {th }}$ July. Treated to a primitive and uncivilised pagan dance called Dedeule - a culturally barren dance in which the indolent native revels. The stench exuding from the unwashed bodies of dancers and drummers is enough to knock out even an Italian.” (94) Yet Mulaisho's novel contains nothing like the ontological undecidability that Achebe sets up around the representation of Ulu, or a representation of a modernist split subjectivity that Gikandi writes about. Instead, Tongue takes up and amplifies the character doubling sketched by Achebe's plot structure.

The sick old man who refuses to regard African medicine as "pagan" in the scene cited at the outset is Father Gonzago, Chief Mpona's mission counterpart. His impending death, willingly embraced, acts as a kind of prompt (if not quite a bark) from the Christian god in the ear of Father Oliver, whose subsequent experience of spatio-temporal discontinuity may arguably be read as a distant echo of Ezeulu's involuntary dislocation. Following a dream in which the notion of witchcraft becomes associated not with "paganism", but with a memory of his own ordination as a Jesuit, Chiphwanya experiences a crisis of temporality different from Ezeulu's. His practice of Christianity assumes "a new direction after the previous one" (Lyotard, 1466). That is to say: he undergoes a radical, miraculous subjectivity 
change, gains sudden insight into the Christ-like quality of Gonzago's acceptance of suffering and is converted to a more authentic (because less opulent, less violent and more culturally empathetic) form of Christianity, aligned with the authentic (i.e. non-violent, decolonising and mindful the pain of others) version of African tradition. Chiphwanya assumes Gonzago's place and becomes a true friend of the villagers whom he had hitherto treated with disdain.

Unlike the "friendship" between Ezeulu and Winterbottom, the personal connection between Mpona and Gonzago (which Lubinda and Chiphwanya disrupt) is unhampered by epistemological incongruence. In Tongue, there is no necessary incompatibility between Christianity and African custom, since the novel imagines authentic versions of both to be predicated on cross-culturally applied humanism. ${ }^{4}$ "The spirits of our ancestors are all good spirits. They do not torture goodness [...]", says an old man in the village. Gonzago (who controversially installs an image of black Christ at the mission around Christmas) echoes those words when he describes the villagers as "'good people' (...) '[t]hey may not be white, but they are human beings"” (149). When he writes about "witchcraft", therefore, Mulaisho does not focus on representing indigenous notions of evil or healing (whose existence and efficiency the novel takes for granted), but the kind of social harm that comes from abuses of political power and a denial of the universal solidarity of suffering.

Undergirding the novel's elaborate plot is a specific alignment of cultural values. African custom and Christian modernity are opposed to each other only under conditions of colonization. They are potentially entirely compatible once the colonial state has been removed, as the novel's ending intimates. Equally mutually compatible are their negations: the abuse of traditional knowledge practiced by Lubinda and Chiphwanya's distortion of Christianity. Both are represented as perversions that result in dehumanisation, violence and death. The perversion of custom ("witchcraft") threatens both genuine custom and genuine Christianity, and the same is true of the perversion of Christianity. The narrative of Arrow 
may be read as an imaginative restoration of a historical moment capable of serving as a symbolic point of national cultural identification and origin ("Umuaro names the particular of which colonial penetration itself is the general”, writes Nicholas Brown (109)). Mulaisho's novel, on the other hand, allegorically stages a process of resignification that effects a realignment and modification of key social categories (“Africans"; "Europeans";

"Christianity"; "tradition") necessary for imagining the emergence of an African national community united by Christianity, and symbolising the rise of a new nationalist bourgeoisie in a time of war. I return to the link between Zambia's national cultures and war in the following section.

In Tongue as in Arrow, the colonial state is inimical to Africans' economic, social, political and cultural well-being. But the novel does not represent anti-colonial resistance as an insurmountable problem. When unwelcome new laws regarding hygiene and the treatment of lepers are imposed on the village, the gentle chief Mpona successfully evades them. Speaking of the state officials in Arrow, Gikandi writes: "Nothing these characters do substantively affects the plot of the novel" (Arrow 12). The same can be said of Tongue. The main threat to the village's survival is not the colonial state, despite its violence. It is the false opposition between Christianity and local beliefs, perpetuated by Chiphwanya's violent parochialism and by Lubinda's self-serving accusations of witchcraft. When these twin threats are removed, the mute child who allegorically represents the official cultural grammar of postcolonial Zambia returns to the village and begins to speak.

Despite its quasi-Achebean insistence on representing village cultures, then, Tongue is less interested in underscoring the distinctions between Nsenga and European cultural and spiritual practices, than in foregrounding their potential for convergence. Readers conditioned to assume that a representation of African everyday life inscribed as a site of ontological and epistemological difference is a necessary precondition of African literariness may see in a 
texts such as this a flattening and a simplification: a derivative, latter-day rendering of the pioneering literary achievement represented here by Arrow.

Such a disparaging reading is exemplified by John Chileshe's locally influential 1983 critical survey of Zambia's written literature. Aiming to assess the progress of Zambian writing towards authentic indigenous literary expression, Chileshe is critical of what he sees as the "evacuation of (...) notions of history and culture" (335) from Mulaisho's novel. Taking it as a given that Mulaisho's novel operates "within the general mode of realism" (341), Chileshe's critique of Mulaisho's text is two-fold. For him, the novel is not a historically accurate representation of Zambian villagers' resistance to colonialism: "this was not even how, on the whole, the people Mulaisho is (re-)presenting reacted historically". (340) Furthermore, Chileshe regards Tongue as remiss in its drive towards "de-historicising 'universalism"”: he finds it "astonishing" that Mulaisho would "surrender even (...) that particularist culturalism which one would normally associate with the pseudo-ethnographic discourse of a first-generation nationalist of the Kenyatta type." (335) Yet Chileshe's remarks regarding the symmetrical structuring of Mulaisho's plot (330) and its "populist-culturalist" (332) elements signal an awareness of another, local, textual tradition - one he dismisses by engaging with it on solely negative terms. This omission leaves him with no other option but to deplore (in a published chapter that summarizes his thesis's conclusions) the "imitation and cultural externality" of the very national canon his study helps to establish (“Educational" 72).

Contra Chileshe, I would contend that an emancipatory awareness of historical events is not "evacuated" from Tongue. Mulaisho's novel is not governed by the conventions of plausibility that mark Achebe's version of realism. Despite its attention to the quotidian and its insistence on the political and cultural complexity of an African society, Tongue does not imagine the colonial conflict and decolonisation in terms of an entanglement of secular 
events that cumulatively amount to a gradual emergence of biographical and/or social "change of epoch". Drawing on a local literary strand with which many of his Zambian readers would have been familiar, Mulaisho constructs a plot whose temporality is structured by two key components: an appropriation of a local version of what Bakhtin called adventure time and the temporal figure of conversion.

In The Dialogic Imagination, Bahktin maintains that adventure time stands in counterdistinction to the temporality of gradual biographical and social becoming. Events that unfold in adventure time do not transmit the characters' maturing: they "are excluded from the kind of real duration in which additions to a normal biography are made" (90). Adventure time is infinite chance time in which the occurrence of events is determined by contingency alone, and human agency is directed at overcoming obstacles. A potential temporal open-endedness is implied in the episodic structuring of adventure-time narratives. It is always possible for a further series of obstacles to present themselves; characters can "experience a most improbable number of adventures" (90). ${ }^{5}$ Among the thematic variants of adventure-time fiction named by Bakhtin in separate, late essay is a time of ordeal, in which characters encounter a series of "tests of their fidelity, valor, bravery, virtue, nobility, sanctity and so on" (Speech Genres 11). By the mid-twentieth century, local versions of ordeal narratives were well established in south-eastern Africa, as Isabel Hofmeyr has established in her illuminating study of the global spread of Bunyan's The Pilgrim's Progress - a seventeenthcentury allegory of a Christian's ordeal on the way to salvation. In Tongue, both Chief Mpona and Father Gonzago undergo ordeals which test their determination to serve the best interests of their communities. Mulaisho solves the problem of how to represent emancipatory social change while operating with becoming-averse adventure time by ending the narrative with the temporal trope of a miraculous, non-gradual subjectivity change: a conversion. The political radicalism of Tongue is contained in its demand for a certain kind of 
European Christian, rather than African "pagans", to be converted. The novel thus represents the necessary conditions of decolonization by constructing a tension-filled temporal structure, which both village and mission participate in producing. This paradoxical manner of inscribing a future on the point of emergence is in keeping with Zambia's political and social circumstances at the time.

\section{Frontline and genre}

In a study of literary and cultural history of western Africa, Stephanie Newell feels compelled to imagine what the history of that region's literature would have looked like if Things Fall Apart had never been published (West African 97). She does so in order to caution against critical devaluation of Achebe's regional predecessors as “irrelevant, flawed or half-fledged as writers", simply because their work does not fit the literary rules set in place by the Achebean gesture of "writing back" to the western canon (98). Among the authors who have been thus critically dismissed are the literary pioneers Cyprian Ekwensi, D. O. Fagunwa and Amos Tutuola. All of them construct their fictions around local versions of adventure time. In the Zambian context, the foregrounding of Achebe's foundational status has, similarly, played a part in a devaluation of parallel literary traditions. And yet, as Newell reminds us, Achebe's literary achievement should not be hastily equated with an expression of mimetically produced cultural authenticity: "[a]t the same time as 'setting the record straight' and highlighting the irretrievable elements of Igbo culture, Achebe (...) occupies a place within the framework of European literary expectations" (West African 100, emphasis added). Franco Moretti's reflections on the global positioning of adventure genres echo Newell's sentiments and offer a related view of the imbalance in the global literary prestige 
that Newell is gesturing towards. Strikingly, Moretti has also felt the need to envisage a strategic suspension of history in order to make a scholarly omission more clearly obvious.

In an essay titled "The Novel: History and Theory", motivated by a rising impatience with "the stranglehold of European 'realism' over the theory and history of the novel" (Distant 159), Moretti imagines what the history of the novel would look like if the entire realism/modernism axis (in which Achebe participates) were to be removed from it. His conclusion: "I'm not sure there is a main branch in the family of forms we call the novel, but if there is one, it's this: we would still recognise the history of the novel without modernism, or even without realism; without adventure in prose, [we would] no[t]." (Distant 166) In so doing, Moretti stresses the need to theorise adventure genres more fully. Like Newell, he points at critically neglected, yet culturally and historically important kinds of textual production, cautioning scholars to pay them more heed in order to avoid the dangers of simplification. Although Moretti's consideration of adventure genres focuses on the massmarket literature of late nineteenth-century Europe, his argument has important implications for the study of Africa's literatures. Prose adventure narratives account for a large section of the continent's fictional production in English. Some of Moretti's preliminary remarks help to provide a starting point for a repositioning of Dominic Mulaisho as a practitioner of what I propose to call frontline realism. Rather than a "flawed or half-fledged" literary figure, frontline realism denotes an African-peripheral form of fighting realism based on adventure time.

In a discussion of the rise of new, mass narrative forms in nineteenth-century Europe, Moretti points out how these forms respond to "[...] extreme situations, and terrible simplifications, that at times history forces one to face" (Distant 31). Among the forms Moretti mentions, detective fiction and science fiction are invoked as exemplary cases of literary forms that are structured in and through the temporality of the adventure plot. What's 
more, his wording acquires an unexpected political relevance in the context of 1970s southeastern Africa. At the time, newly independent Zambia had no choice but to contend with the "terrible simplifications" of white supremacist discourse, still hegemonic in settler colonies elsewhere in the region. Between 1964 and 1994, Zambia accommodated within its borders the liberation movements from South Africa (ANC), Namibia (SWAPO) and today's Zimbabwe (ZAPU). Moretti surmises that "the reason adventure works so well [within the context of capitalism on the offensive] is that it's so good at imagining war" (Distant 177, emphasis in the original). Such a statement is particularly apposite for reading Dominic Mulaisho's first novel, which allegorises the coming-to-independence of a frontline state.

In counter-distinction to Nigeria, Zambia's post-independence literary expressions of cultural nationalism were always-already tempered with textual concerns related to colonial oppression that was continuing elsewhere in the region. Local writers were thus compelled to pay close attention not only to the evolving Pan-African literary canon, but also to local writing which could be mobilised in constructing social imaginaries related to local (national and regional) emancipation. It is partly as a result of this cultural dynamic that Zambia's literature in English came to diverge from what became the mainstream direction of Africa's global literary consecration - a direction which continued to be shaped and directed by Achebe's literary output. ${ }^{6}$

The cultural logic of Mulaisho's novel is thus not primarily to do with writing back to the Euro-Atlantic canon or to the language of Eurocentric literary critics. In a much-cited essay on the flaws of colonialist criticism, Achebe wanted to see "the word universal banned altogether from discussions of African literature until such time as people cease to use it as a synonym for the narrow, self-serving parochialism of Europe; until their horizon extends to include all the world" (Morning 13, emphasis in the original). When, by contrast, Mulaisho's novel posits a universally applicable notion of humanity in which Africans participate, this 
literary gesture is in keeping with Kenneth Kaunda's Christian, Anglophone, anti-tribalist frontline cultural policy of the time. The lesson that the culturally arrogant, parochially minded Chiphwanya learns from the dying Gonzago - that a moral obligation is owed to all human beings based solely on their humanity, without reference to race, nationality, ethnicity, gender or other communal particularities - is an expression of a cultural and political stance I have called frontline cosmopolitan ("At Home"). Thus, although Tongue is built around sharply contrasted characters, the ethical backbone of the novel's plot lies precisely in its frontline-cosmopolitan refusal to evaluate them according to the criteria of race, class, nationality or culture. Within the temporal structure of Mulaisho's novel, sacrifice and conversion are separated from each other, and both are separated from ordeal: the novel assigns each of these narrative figures to a different subject/group of subjects across the colonial, national and gender divides: Gonzago, Chiphwaya and villagers of both genders, respectively. Thus the plot's temporal configuration (made possible by adventure time) is performed by a frontline-cosmopolitan cross-cultural collaboration, which symbolically ushers in Zambia's independece. In Arrow, by contrast, the temporality that marks the arrival of colonial modernity is tied to Ezeulu alone: either as the character who unwittingly buys into it (in Gikandi's reading), or as the site of its ontological enactment (in Mathuray's), as I outlined above.

Mulaisho's readers are invited to contrast the non-aggressive inside-outsiders with their manipulative, violent challengers, across communal difference. In the world of Tongue, "god's arrows" - the narrative agents who become the carriers of emancipatory future possibilities - are not internally divided. They are, rather, composite - constituted via a confluence of several characters' actions and motivations, as in the case of the hard-won brotherhood between Mpona and Gonzago, or the newfound speech of the mute village child who loses a father to witchcraft but is cured of his handicap in a modern city hospital. The 
figure of a mute child coming to speech both allegorises the coming to independence of the Zambian nation and points to a specific local fictional tradition which endows the novel with its overall narrative shape and stamps it with a recognisably Zambian identity. In conjunction with a representation of rural communities beset by hunger, the figure of a speechless child who inhabits a world beset by suffering evokes Mulaisho's most prominent Zambian precursor: the great Bemba novelist Stephen Mpashi, whom Mulaisho knew persionally and with whose work he was closely familiar (Primorac "Lazymen's"). In particular, Tongue borrows several textual elements from Mpashi's 1956 masterpiece, Pano Calo (This World).

Stephen Mpashi helped to lay the foundation of Zambian literariness as an editor at the Joint Publications Bureau of Northern Rhodesia and Nyasaland in the colonial era. He was a nationalist sympathiser, close to Zambia's first president Kenneth Kaunda (Betty Kaunda). Kalunga Lutato has shown how Mpashi's novels, directed at the newly-literate urban readerships on Zambia's Copperbelt (where Bemba was lingua franca), effect a synthesis of Bemba oral and Christian written textual forms. Particularly noteworthy in the present context is Mpashi's familiarity with the Bemba translation of Bunyan's The Pilgrim's Progress, because it helps to trace a textual route via which Christian ordeal narratives entered and became localised in Zambia's literary space. ${ }^{7}$ Pano Calo is a fantasy narrative that can be read as an allegory of modernisation carried out on Bemba cultural terms: the story culminates in Bemba villagers' acceptance of the Christian god who is imagined as one of them: a spiritual incarnation of an orphaned village child. The novel features a mute child, a protracted period of village famine, and, centrally, a story of the dovetailing ordeals endured by the village man called Kampinda and his wife Namukonda. These ordeals culminate in death, which the narrative frames as a form of punishment for Kampinda's and Namukonda's self-centred disregard for the lives of others. 
Mulaisho's novel appropriates Pano Calo's strategy of narrating multiple village ordeals. In addition to the trials of Mpona and Gonzago, Tongue narrates the near-endless ordeals of the village teacher and Natombi, the widowed mother of a mute child. Both of them are, as the novel repeatedly stresses, outsiders: the teacher is a Christian, Natombi - a stranger to the village, who has dared to repulse Lubinda's advances. "They say that the citizens of a village are like roots: they meet underground", says the novel's narrator. "But the roots of one person did not meet underground with those of the other people. This person was Natombi." (113) The teacher, too, is an isolated outsider: "'Stranger, you come from far across the Luangwa, from the country of the unknown."”, a villager tells him (172). Like Pano Calo, Mulaisho's novel represents kindness to strangers as a measure of ethical conduct, and the ability to withstand an extended ordeal that takes one to the very brink of death (and tests one's determination to survive without compromising the cosmopolitan ethical ideal) as the only way of acquiring a non-superficial understanding of "this world". If Mpona and Chiphwanya are Zambian textual descendants of Ezeulu and Winterbottom, then teacher and Natombi are the literary inheritors of Kampinda and Namukonda. Even as he embraced pan-African nationalist pride in embracing Achebean techniques of representing village life while asserting the complexity and validity of indigenous cultural practice, Mulaisho (alongside other Zambian writers) chose to build on, rather than break away from, his nation-state's emancipatory colonal-era literary heritage.

In constructing his novel in the way he did, Mulaisho was activating a foundational Zambian literary narrative: a story of selfhoods shaped by suffering, in which the weak maintain perseverance in the face of the need to overcome proliferating obstacles. Isabel Hofmeyr has demonstrated the emancipatory potential of twentieth-century African appropriations of the ordeal narrative that is The Pilgrim's Progress. Bunyan was introduced to Africa by Christian missionaries complicit in the project of colonisation. Yet his story of a 
prolonged test of faith undergone by a troubled and tortured man who is finally able to shed his heavy load was disseminated and translated with Africans' participation, and it enabled African readers and writers to think and write about the possibilities of their own emancipation. That Mulaisho's Tongue commanded similar emancipatory potential in Zambia's frontline decades seems clear: its insistence on the humanity of Africans was in keeping with the political agendas of regional anticolonial struggles at the time. Nor does the genre-related divergence between Arrow and Tongue stand in the way of broader cultural resonance between Achebe's and Mulaisho's texts: Ezeulu's existential alienation resonates strongly though complexly with the isolation, doubt and angst of Mulaisho's abandoned teacher. Dominic Mulaisho's Tongue is thus both world-facing (extroverted, as Eileen Julien would put it) and introverted - i.e. deeply interwoven with regional understandings of what literature is and can do. Mulaisho can be accused of "cultural externality" no more convincingly than Achebe can. On the contrary: by skilfully appropriating elements of Achebean fighting realism and combining them with other (similarly complex) textual conventions, Mulaisho was participating in the regional articulation of the world's and Africa's literary systems of his day. This kind dynamic is entirely lost from view if Zambia and other parts of Africa are cast as "literary deserts" and removed from sustained literarycritical consideration.

Isabel Hofmeyr's study of the "portable" Bunyan is important in the present context not least because it offers a methodology of studying the transnational circulation of books, texts and forms which can be adapted to make scholarly views of Africa's literatures more inclusive and nuanced. Her account of the movement, appropriation and re-literarisation of Pilgrim's Progress (which moved from a position of cultural consecration as a "universal" narrative, to becoming an "English" text early in the twentieth century) may be read as a critique and corrective of WReC's and Moretti's world-systems approach to world literature. 
Hofmeyr sets a carefully historicised precedent for a dynamic, multi-directional, multi-scale view of what constitutes "centres" and "peripheries" of transnational literary flows. By outlining the "sideways" movement of texts between different economic peripheries, The Portable Bunyan enables a scholarly imagination of a hierarchy of centres and peripheries within an "intellectually integrated" (Hofmeyr 24) textual space such as the British Empire, or (differently, in the present day), Anglophone Africa. A scholarly view of Africa's literary history alert to the necessity of investigating multiple textual genealogies and genreformation histories facilitates the formulation of a Morettian question that Moretti himself does not ask: what are the historical dynamics that drive Africa's capacity to produce new forms? The deployment of various kinds of "African" literary capital that Mulaisho brought to the making of his first novel granted that novel only a temporary and marginal presence in the world literary marketplace. Yet the present historical moment (which saw the fiftieth anniversary of Arrow marked by global celebrations and tributes in 2014) is an opportune one for reflecting on and retracing Africa's multiple literary pasts, because the global visibility of adventure-based fictions emanating from the African continent is on the rise.

African appropriations of detective, speculative and commercial-genre fiction have attracted the attention of all kinds of readers in the past decade or so. In south-eastern Africa, recent ecent novels by Ellen Banda-Aaku, Lauren Beukes, Panashe Chigumadzi and Petina Gappah (to name but a few) all contain textual elements related to adventure narratives of ordeal. The works of these and other authors may arguably be related to local forms and publications in ways that are rendered unthinkable if "African literature" is related only to a narrow, eurocentrically constructed, spectrum of fictional temporal forms and textual genealogies. Elsewhere, globally prominent literary practitioners whose work is consecrated as "African" have repeatedly objected to the prescriptive generic pigeonholing of their work. When the Sierra Leonean/British author Aminatta Forna was asked why she had left the 
terrain of writing about Africa and Africans altogether in her latest novel, The Hired Man (set in Croatia), she wrote that it is "the way of literature to seek universality". Her claim resonates with Mulaisho's non-apologetically universalistic poetics and reads as a direct rejoinder (written decades later) to Achebe's deferral of his own willingness to use the term “universal” in literary analysis. In Zambia itself, Mulaisho’s locally-published literary descendants continue to write and publish under difficult material circumstances. Authors who write in Tongue's wake include Grieve Sibale, Norah Mumba, Binwell Sinyangwe and Kachinga Shichizya. One of them, Sekelani Banda, recently published an articulate defence of his own practice in the face of critical dismissals. He writes: "As a practitioner in literature, not a scholar, I humbly submit that norms can only ever be interim, and values must be contextualised." (620) In the present contexts, this sentence serves as a welcome and timely warning against reducing "Achebe" to a normative abstraction. In a recent study, Pheng Cheah normatively links the category "postcolonial world literature" with narrative fiction's capacity to effect temporalities of persistence that open out onto new worlds. In Africa as elsewhere, such emancipatory temporal constructs come in multiple genre forms. Although Cheah's use of the notion of "persistence" is distinct from the temporal terminology this article relies on, the word resonates suggestively with Dominic Mulaisho's emancipatory, future-facing fictional ordeals.

In view of all this, Tongue deserves a more detailed contemporary rereading. In the present context, some brief suggestions as to its possible directions will have to suffice. The novel's patriarchal representation of women sets a partial limit to its cosmopolitan aspirations and demands to be juxtaposed with the work of Zambia's women writers. (Two of them, Norah Mumba and Monde Sifuniso, have edited a collection of feminist short stories titled The Heart of a Woman. The title is a direct quote from Tongue as well as an intertextual reference to Maya Angelou.) Written in a historical moment of political crisis, Mulaisho's 
novel arguably has the capacity to open itself out to his region's political concerns of today. Frederic Hale has noted Mulaisho's attention to multiple of practices of whiteness: in the historical present, this aspect of Tongue may be approached as a fictional theorisation of the possibilities of racial conviviality in former settler colonies. (In chapter ten, for example, Gonzago explicitly and sincerely submits to Mpona's political authority, thereby cancelling out his own position of racialized privilege: “'We are your people, Chief,' he said to Mpona, 'look after us well."” (159).) Lubinda's persecution of his enemies with accusations of witchcraft and the theme of witch-hunting that runs through the novel may today be construed as a prescient representation of postcolonial state terror in Southern Africa - for example, the ruling party's persecution of "sellouts" in twenty-first century Zimbabwe. The word "terror" recurs repeatedly in Tongue. At the end of chapter 13, as the villages commence the wait for the outcome of Mpona's witchcraft trial, a descriptive passage states:

A cold wind blew over the skins of the debaters. Someone stood up, yawned, and stretched himself, and shouted, 'It is daybreak! The Chief is well!'. The people put out the fires, for there was no longer any mourning. But how could people go back to Ciwera or Mkando or Cakuwamba without understanding the events of that whole night of terror?" (214).

The word "terror" is here endowed with political connotations (since Lubinda, as a would-be Chief, has engineered a "constitutional problem" (214) by accusing the Chief of wrongdoing). The context of its use resonates uncannily with Achille Mbembe's description of nativist approaches to history as embodying a belief in "history as sorcery", in his influential discussion of African modes of self-writing. (245)

"To ignore genre is to ignore a text's relation to history and social context", writes Karin Barber (Anthropology 44). Both Arrow and Tongue have the capacity to be read as 
novels of ruination and renewal, destruction and utopia. Critically reconsidering Africa's adventure-time fictional traditions may help to bring into analytical view the hitherto neglected African social and literary contexts. If WReC's critical manifesto of making world literary studies less Eurocentric and more inclusive is to make any sense on the African continent, it has to question more radically the idea that globally circulating texts and genres alone can provide an accurate idea of the kinds of literary production that participates in inscribing capitalist modernity on global economic peripheries. A properly cosmopolitan literary-historical practice should know better than to equate the cultural relevance of texts and forms with their relative prestige in the unevenly structured global literary marketplace, or to blithely assume an absence of valid non-globalised notions of literariness and literary value. In that early post-independence musing on the "literary barrenness" of his own part of Africa (which, however, does not mention literary deserts), Taban Lo Liyong nevertheless advocates making east African works, too, the subject of study. This is entirely in keeping with the life-work and legacy of Chinua Achebe. He was, after all, the elite, globally revered author and public intellectual who wrote the gracious foreword to Emmanuel Obiechina's study of Onitsha market "pamphlets" - in which he grants Onitsha's market fictions, as a matter of course, the status of literature. 
Endnotes

1 After AOG, Mulaisho published another novel AWS, the 1979 The Smoke that Thunders. Since then, Ellen Banda-Aaku won the inaugural Penguin Prize for African writing in 2010, which resulted in the publication of her novel Patchwork by Penguin South Africa in 2011. Novelist-to-be Namwali Serpell won the Caine Prize for African Writing in 2015; her novel in progress, provisionally titled The Old Drift, has been contracted to Hogarth Press.

2 A discussion of the disparity between Nigeria's and Zambia's economies and their institutional and educational resources in the era of decolonization and other social and cultural factors that contributed to this relative difference of the two countries' standing in the African republic of letters must remain outside the scope of this article. For partial yet suggestive accounts, see Chilala, Chileshe Literacy, Innes and Ochiagha.

3 I am grateful to Professor Akachi Ezeigbo for the translation of these sentences into English.

4 Like Achebe's nationalism and the Zambian humanism of Mulaisho's day, TOD's humanism (and the novel's explicit concern with women's social positioning) can be described as patriarchal.

5 In that respect, it is indicative that $A O G$ represents Ezeulu's final madness as the biographical moment of that character's final decline. Chief Mpona, on the other hand, is at TOD's outset represented as coming out of an episode of madness. The novel's plot drives him inexorably towards the possibility of another.

6 For a contemporary practitioners' intervention into the debate on African literature and the burden of representation, see Forna and Selasi.

7 The Bemba translation of Pilgrim's Progress is mentioned by a character in Mpashi's 1957 novel Uwakwensho bushiku (A Detective Story), the first part of the diptych Pio na Vera (Pio and Vera).

\section{ACKNOWLEDGEMENTS}

I presented versions of this article at academic events held at Senate House (University of London), Rhodes University and the University of Cambridge: I am grateful to all those who offered critical suggestions and comments on those occasions. Online conversations with fellow African Literature Vuvuzelites - Bwesigye Bwa Mesigire, Grace Musila and Thando Njovane - provided a laughter-filled backdrop to the process of drafting the final version. I am indebted to Stephen Morton for collegial generosity and astute textual suggestions. 


\section{Works Cited}

Achebe, Chinua. Arrow of God. 1964. London: Penguin, 2010

---------. Morning yet on Creation Day. New York: Doubleday, 1975.

Banda-Aaku, Ellen. Patchwork. Johannesburg: Penguin, 2011.

Banda, Sekelani. “A Zambian Author's Contestation of Common Perspectives on SelfPublishing”. Journal of Southern African Studies 40.3 (2014): 615-621.

Barber, Karin. The Anthropology of Texts, Persons and Publics. Cambridge: Cambridge University Press, 2007.

Barthes, Roland. The Rustle of Language. Transl. Richard Howard. London: Basil Blackwell, 1986.

Bakhtin, M.M. Dialogic Imagination. Transl. Caryl Emmerson and Michael Holquist. Ed. Michael Holquist. Austin: University of Texas Press, 1981.

Bakhtin, M.M., Speech Genres and Other Late Essays. Transl. Vern W. McGee. Ed. Caryl Emmerson and Michael Holquist. Austin: University of Texas Press, 1986.

Bgoya, Walter and Mary Jay. "Publishing in Africa from Independence to the Present Day." Research in African Literatures 44. 2 (2013): 17-34.

Barnett, Clive. "Disseminating Africa: Burdens of Representation and the African Writers Series”. New Formations 57 (2006): 74-94.

Brouillette, Sarah, Postcolonial Writers in the Global Literary Marketplace. Basingstoke: Palgrave, 2011.

Brown, Nicholas. Utopian Generations: The Political Horizon of Twentieth-Century Literature. Princeton: Princeton University Press, 2005.

Caine Prize for African Writig. "How to enter". http://caineprize.com/how-toenter/ Accessed 30 April 2017.

Casanova, Pascale. The World Republic of Letters. Transl. by M. B. DeBevoise. Cambridge, Mass: Harvard University Press, 2004.

Cheah, Pheng, What is a World? Durham and London: Duke University Press, 2016.

Chilala, Cheela Himutwe K., "Anatomy of Challenges Facing Zambian Writers and Publishers of Literary Works". Journal of Southern African Studies 40.3 (2014): 593-606. 
Chileshe, John. "Educational and Linguistic Constraints: On the Development of National Literature in Zambia." Mapping Intersections: African Literature and Africa's Development. Ed. Anne V. Adams and Janis A. Mayes. Trenton and Asmara: Africa World Press, 1998. 6177.

Chileshe, John. Literacy, Literature and Ideological Formation: The Zambian Case. PhD thesis. University of Sussex, 1983.

Chinweizu, “Beyond European Realism”, Okike 14 (1978): 1-3.

Ferguson, James. Expectations of Modernity. Berkeley: University of California Press, 1999.

Forna, Aminatta. "Don't judge a book by its author". The Guardian, UK, 13 Feb 2015.

Theguardian.com/books/2015/feb/13/aminatta-forna-don't-judge-book-by-cover

Foucault, Michel. "What is an Author?". The Norton Anthology of Theory and Criticism. Ed. Vincent B. Leitch et al. New York: W. W. Norton, 2010. 1475-1489.

Gikandi, Simon. "Arrow of God (Chinua Achebe, 1964)". The Novel Vol.2: Forms and Themes. Ed. Franco Moretti. Princeton: Princeton University Press, 2007. 489-496.

"Arrow of God: the Novel and the Problem of Modernity". Text of F. T. Prince lecture, Southampton University, October 23, 2014. [To be replaced by reference to article published in this issue]

Reading Chinua Achebe. Oxford: James Currey, 1991.

Hale, Frederic. “Jesuit Missionary Types and Nsenga Responses in Dominic Mulaisho's The Tongue of the Dumb". Zambezia 16.2 (1999): 211-226.

Hitchcock, Peter. The Long Space. Stanford: Stanford University Press, 2010.

Hofmeyr, Isabel. The Portable Bunyan: A Transnational History of The Pilgrim's Progress. Princeton: Princeton University Press, 2004.

Huggan, Graham. The Post-Colonial Exotic. London: Routledge, 2001.

Innes, C.L. Chinua Achebe. Cambridge: Cambridge University Press, 1990.

Irele, Abiola F. "The Crisis of Cultural Memory in Chinua Achebe's Things Fall Apart". African Studies Quarterly 4.3 (2000): 1-40.

JanMohamed, Abdul. Manichean Aesthetics: The Politics of Literature in Colonial Africa. Amherst, Mass: The University of Massachusetts Press, 1983.

Julien, Eileen. "The Extroverted African Novel". The Novel, Vol. I: History, Geography and Culture. Ed. Franco Moretti. Princeton and Oxford: Princeton University Press, 2006. 667700 . 
Krishnan, Madhu. Contemporary African Literature in English: Global Locations, Postcolonial Identifications. Houndmills, Basingstoke: Palgrave MacMillan, 2014.

Lindfors, Bernth. "Politics, Culture and Literary Form". African Literature: An Anthology of Criticism and Theory. Ed. Tejumola Olaniyan and Ato Quayson. Oxford: Blackwell, 2007. 22-30.

Lazarus, Neil. The Postcolonial Unconscious. Cambridge: Cambridge University Press, 2011.

Lo Liyong, Taban. The Last Word. Aylesbeare: Mallory, 2006 [1969].

Lutato, Kalunga. The Influence of Oral Narrative Tradition on the Novels of Stephen A. Mpashi. PhD. Thesis. University of Wisconsin-Madison, 1980.

Lyotard, Jean-François. "Defining the Postmodern." The Norton Anthology of Theory \& Criticism. Ed. Vincent B. Leitch et.al. New York: W. W. Norton \& Co, 2010. 1465-1468.

Mathuray, Mark. On the Sacred in African Literature. Houndmills: Palgrave, 2009.

Mbembe, Achille. “African Modes of Self-Writing”. Public Culture 14. 1 (2002): 239-273.

Moretti, Franco. Distant Reading. London: Verso, 2013.

Mpashi, Stephen A. Betty Kaunda. Lusaka: Longmans, 1969.

Pano Calo. Lusaka: Zambia Educational Publishing House, 2009 [1956].

-------------- Pio na Vera. Lusaka: Bookworld Publishers 1996 [1968].

-------------- Pion a Vera. Transl. Wycliffe C. Mushipi and Kalunga Lutato. Unbupl. Ms, 2016.

This World. Transl. Wycliffe C. Mushipi. Unpubl. Ms, 2012.

Mulaisho, Dominic. The Tongue of the Dumb. 1971. Lusaka: Maiden, 2007.

Mulaisho, Dominic. The Smoke that Thunders. 1979. London: Heinemann.

Mumba, Norah and Monde Sifuniso (eds). The Heart of a Woman: Short Stories from Zambia. Lusaka: ZWWA, 1997.

Newell, Stephanie. West African Literatures: Ways of Reading. Oxford: Oxford University Press, 2006.

New Writers Group. Editorial. New Writing from Zambia 8.3 (1972): 2.

Ochiagha, Terri. Achebe and Friends at Umuahia: The Making of a Literary Elite. Woodbridge: James Currey, 2015.

Phiri, Masautso. “A General Survey of Creative Writing in Zambia”. Zango 6 (1979). 
Primorac, Ranka. "At Home in the World? Re-Framing Zambia's Literature in English". Journal of Southern African Studies 40.3 (2014): 575-591.

"The Modern City and Citizen Efficacy in a Zambian Novel". Journal of Postcolonial Writing 44.1 (2008): 49-59.

"Lazymen's Clinic: A Musing on Everyday Life and Research". Popular Culture in Africa: The Episteme of the Everyday. Ed. Stephanie Newell and Onookome Okome. New York: Routledge, 2014.

------------ "Legends of Modern Zambia”. Research in African Literatures 43.4 (2012): 5070.

"An Overshadowed Literature: Mapping the Field". Available at http://jahnbibliothek.ifeas.uni-mainz.de/310 ENG HTML.php .

Quayson, Ato. "Self-Writing and Existential Alienation in African Literature: Achebe's Arrow of God". Research in African Literatures 42.2 (2011): 30-45.

Roscoe, Adrian and Mpalive Msiska. The Quiet Chameleon: Modern Poetry from Centrala Africa. London: Hans Zell, 1992.

Said, Edward. "From Orienatlism". The Norton Anthology of Theory and Criticism. Ed Vincent B. Leitch. New York: W. W. Norton \& Company, 2010. 1866-1888.

Selasi, Taiye. "Stop pigeonholing African writers". The Guardian, UK, 4 July 2015. theguardian.com/books/2015/jul/04/taiye-selasi-stop-pigeonholing-african-writers Sichizya, Kachinga. Uneasy Yoke. Lusaka: Maiden, 2005.

Wamulume, Godwin. "Why do Zambian authors fail 2 [sic] obtain recognition". 14 March 2016. Facebook.

WReC. Combined and Uneven Development: Towards a New Theory of World-Literature. Liverpool: Liverpool University Press, 2015. 